\title{
VARIABILITY OF GROUNDWATER FLOW AND TRANSPORT PROCESSES IN KARST UNDER DIFFERENT HYDROLOGIC CONDITIONS
}

\author{
SPREMENLJIVOST PRETAKANJA VODA IN PRENOSA SNOVI \\ V KRASU OB RAZLIČNIH HIDROLOŠKIH POGOJIH
}

Nataša RAVBAR ${ }^{1}$

\begin{abstract}
UDC 911.2:551.444

$556.33: 551.44$

Nataša Ravbar: Variability of groundwater flow and transport processes in karst under different hydrologic conditions Significance of hydrological variability in karst is presented, which also discusses factors inducing such variability and consequences it may cause. Groundwater flow in karst aquifers is often characterized by strong variability of flow dynamics in response to different hydrologic conditions within a short time period. Consequently, water table fluctuations are often in the order of tens of meters, differences in flow velocities between low- and high-flow conditions can reach ten or even more times. In dependence to respective hydrologic conditions groundwater flow also results in variations of flow directions, and thus in contribution of different parts of the aquifer to a particular spring. The described hydrological variability has many implications for contaminant transport, groundwater availability and vulnerability. Groundwater level rising reduces thickness of the unsaturated zone and decreases protectiveness of the overlying layers. Higher water flow velocities reduce underground retention. Due to more turbulent flow, transport and remobilization of solute and insoluble matter is more effective. During high-flow conditions there is usually more surface flow and hence more concentrated infiltration underground. Particularly in karst systems that show very high hydrologic variability, this should be considered to correctly characterize, understand or predict the aquifers' hydrological behaviour and to prepare proper protection strategies.
\end{abstract}

Keywords: karst aquifer, temporal hydrological variability, groundwater flow, transport processes, karst spring, water source protection.
Izvleček

UDK 911.2:551.444

556.33:551.44

NatašaRavbar:Spremenljivostpretakanjavodainprenosasnovi v krasu ob različnih hidroloških pogojih

Predstavljeni so pomen hidrološke spremenljivosti v krasu, dejavniki, ki sprožajo tovrstno spremeljivost in posledice. Za pretakanje podzemnih kraških voda je značilna velika spremenljivost $\mathrm{v}$ odvisnosti od različnih hidroloških razmer. Nihanja podzemne vode se lahko spreminjajo za več deset metrov, razlike $\mathrm{v}$ hitrostih pretakanja voda ob nizkem ali visokem vodostaju so lahko deset ali večkratne. Glede na trenutne hidrološke razmere pogosto prihaja do spreminjanja smeri podzemskega toka, kar lahko povzroči različno prispevnost določenih delov vodonosnika $\mathrm{k}$ individualnemu izviru. Opisana hidrološka spremenljivost pa lahko izrazito vpliva na transport onesnaževal, na razpoložljivost podzemne vode ter na njeno občutljivost na onesnaženje. Dvig gladine podzemne vode povzroča zmanjšanje debeline nezasičene cone in $\mathrm{s}$ tem nižjo samočistilno sposobnost prenikajočih vod. Višje hitrosti pretakanja voda vplivajo na krajše zadrževalne čase $\mathrm{v}$ podzemlju, podzemni tok je bolj turbulenten in zato transport in mobilizacija topnih in netopnih snovi bolj efektivna. Zato je posebno na kraških območjih, za katere je značilna velika hidrološka spremeljivost, to lastnost potrebno upoštevati pri proučevanju, razumevanju ali napovedovanju hidrološkega obnašanja vodonosnika, ali pri pripravi ustreznih postopkov varovanja.

Ključne besede: kraški vodonosnik, časovna hidrološka spremenljivost, transportni procesi, kraški izvir, zaščita vodnega vira.

${ }^{1}$ Karst Research Institute ZRC SAZU, Postojna, Slovenia, e-mail: natasa.ravbar@zrc-sazu.si 


\section{INTRODUCTION}

Since recognition of the significance of karst aquifers as important water resource and valuable ecosystems is growing worldwide, these hydrological systems are receiving rapidly increasing attention from the scientific, engineering and regulatory communities. Due to the many challenges related to their characterization and management, such aquifers require good knowledge and comprehension of groundwater flow characteristics (Bakalowicz 2005; Goldscheider \& Drew 2007; Bonacci et al. 2009; Kresic \& Stevanovic 2010).

Karst hydrogeologic systems are associated with a high level of heterogeneity encountered in karstified rocks that is manifested in a duality of fundamental hydraulic processes occurring in the aquifer (Király et al. 1995; Worthington 1991). The hydrogeological heterogeneity concern aquifer recharge (diffuse/concentrated), storage and porosity (pores and micro-fractures/ conduits), and discharge (diffuse/concentrated). Unlike all other aquifer types, flow behavior in karst aquifers exhibits rapid or immediate infiltration, close interrelationship between surface and groundwater, high underground flow velocities (reaching up to several hundred meters per hour) and high conductivity in the prevailing conduit systems. There are frequently connections and intersections of water paths over large distances (up to many tens of kilometers). Due to the specific nature of karst aquifers, the system response to recharge processes is also controlled by the manner in which infiltrating water is transmitted through the aquifer. Consequently, karst hydrological systems may be very sensitive to changes in the hydrometeorological conditions of recharge. Hydraulic reactions to different hydrologic conditions may result in differences of flow which is relevant in many respects (White 1988; Bakalowicz 2005; Ford \& Williams 2007).

Accordingly, behavior of karst aquifers is often unpredictable and their water resources are extremely vul- nerable to contamination, over-exploitation and climate change (Drew \& Hötzl 1999). Ignoring these described characteristics, when carrying out hydrogeological investigations in carbonate aquifers, when confronting specific environmental and engineering problems or when planning management of groundwater resources, is potentially erroneous. Moreover, investigating and planning in karst requires special adaptations of investigation techniques, avoiding generalizations and/or interpolations (Goldscheider \& Drew 2007; Milanović 2006; Sass \& Burbaum 2010). Holistically taking into account the karstic nature of carbonate aquifers therefore represents a key step toward appropriate investigation and planning in karst.

Many excellent publications prove that the uniqueness of water flow in karst is already very well known and appreciated, at least among those academicians, practicing hydrogeologists, and water resources professionals who regularly deal with karst and karst related problems. General specifics of water flow in karst are also adequately abided in various studies, expertise, when choosing research methods, solving problems, etc. However, temporal hydrological variability is considered in a minor degree, although some karst systems (e.g. Dinaric karst, karst under sub-tropical/monsoon climates) exhibit considerable hydrologic variability. There is also a lack of readily available research systematically studying the role of temporal variability in karst.

Therefore the aim of this contribution is to list the reasons for temporal hydrologic variability, and to discuss its relevance to questions of karst aquifer behavior, as well as groundwater availability and protection. Some case studies that illustrate variability of groundwater flow and transport processes in karst under different hydrologic conditions are presented, and stress the importance of considering hydrologic variability.

\section{KARST AQUIFER HETEROGENEITY AND TEMPORAL HYDROLOGICAL VARIABILITY}

From a hydrogeological perspective, the most distinctive property of karst aquifers that differentiate them from other hydrogeological systems is the high solubility of the rock medium determining the high heterogeneity of hydraulic aquifer properties (White 1988; Ford \& Williams 2007; Klimchouk \& Ford 2000; Király 2002). The duality and heterogeneity of karst is reflected in a fast water com- ponent with a low storage capacity in conduits (preferential flow) on one hand, and the slow water flow and high storage capacity component in the fissured-porous karst system (diffuse flow) on the other hand.

Solutional enlarging of fissures being the unique hydrogeological characteristic of karst rocks makes them highly permeable and enables immediate infiltration of 


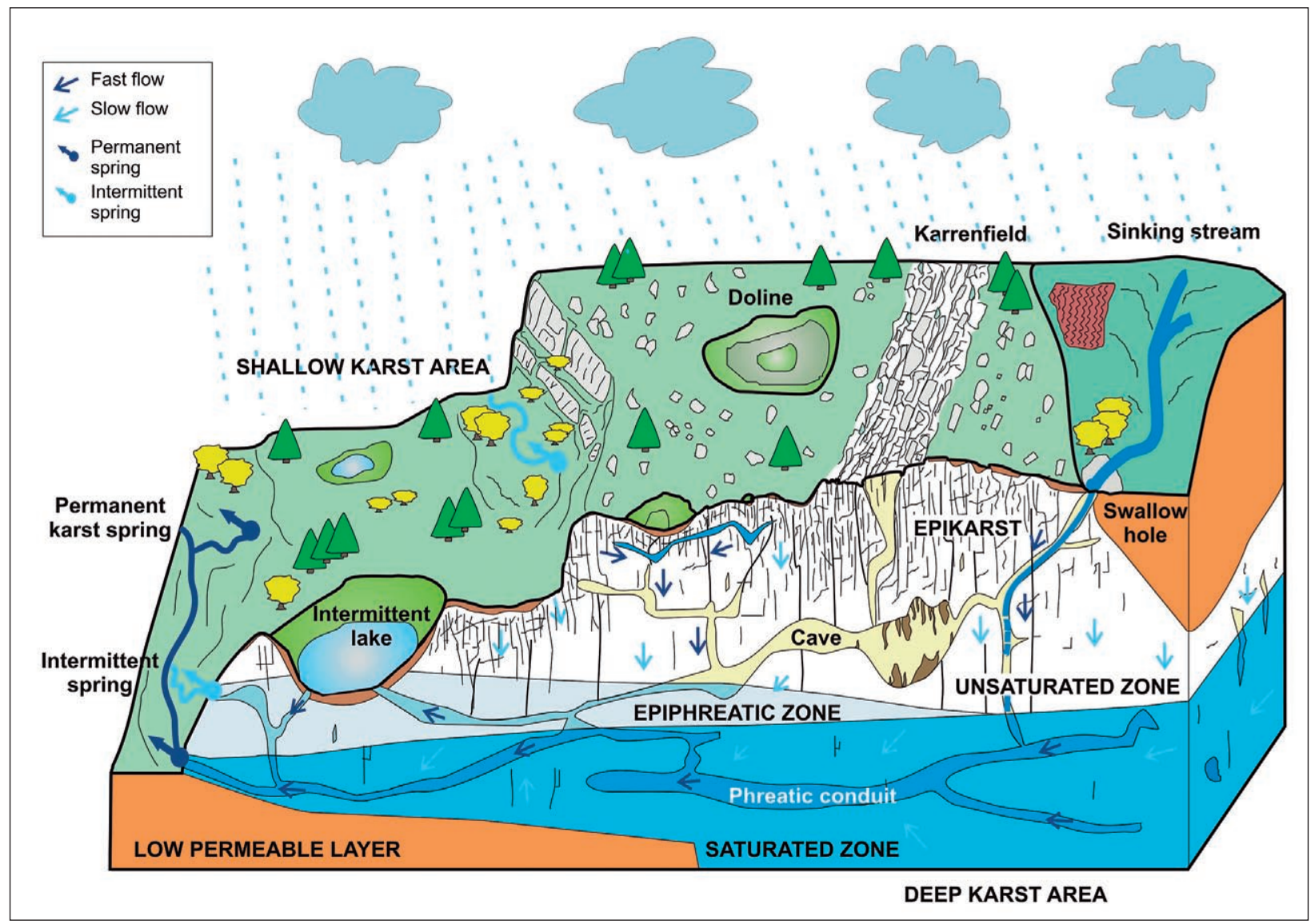

Fig. 1: Conceptual three-dimensional model of karst aquifer and groundwater flow, illustrating the heterogeneity of karst: allogenic and autogenic type of recharge, point and diffuse infiltration, flow through conduits and low permeability matrix (modified after Ravbar 2007).

water into the subsurface. In the underground it creates cavities organized in a flow net in a hierarchical manner (Bakalowicz et al. 1994; Gabrovšek 2000). The underground drainage system is then integrated into efficient, mainly sub-horizontally oriented conduits for the collection, transport and ultimately discharge of recharge waters (Fig. 1). Although the karst conduit system occupies only a small portion of the total aquifer porosity, it may have a major impact on the specific hydraulic behavior of the karst system.

Among the special properties of water flow in some karst aquifers, fast and strong hydrologic variations in response to precipitation events or snowmelt are often shown. These strongly depend on hydrometeorological and hydrogeological factors. The first group of factors includes the type, amount, intensity and distribution of precipitation, and factors governing snowmelt, such as temperature and wind. The second group comprises catchment size, aquifer geometry, effective porosity, the dimensions and connectivity of the karst conduits and the antecedent soil moisture.
These variations may include:

a) significant groundwater level fluctuations;

b) changing flow directions;

c) changing flow velocities;

d) change from open-channel to pressurized flow;

e) change from laminar to turbulent flow.

Consequently, shifting groundwater divides and different types of surface-groundwater interaction, such as activating temporarily active streams, swallow holes, etc. can be observed. Likewise, the hydrologic state of estavelles changes. Spring water physical and chemical properties may be subject to significant variability as well. These variations are relevant with respect to contaminant transport and groundwater availability and vulnerability 


\section{CASE STUDIES}

\section{WATER TABLE OSCILLATIONS AND DIFFERENCES IN GROUNDWATER FLOW}

Groundwater level variations in karst aquifers are often on the order of tens of meters within a short time period. They may result in variations of flow velocities and directions, in divergent flow and consequently in shifting catchment boundaries, and surface-groundwater interactions. Strong water table oscillations are particularly pronounced in the Dinaric karst that stretches along the Adriatic coast, characterized by vast karst plateaus intersected by karst poljes. In the famous cave system of Škocjanske Jame, water levels can rise up to about $100 \mathrm{~m}$ (Habe 1966). In Popovo Polje in Bosnia and Herzegovina, the largest karst polje in the Dinaric karst, the highest variations are recorded at more than $200 \mathrm{~m}$ (Milanović 2006).

Particularly at the intermediate karst poljes, shallow karst areas or in the contact karst areas, various forms of interaction between groundwater and surface water can be observed as well. Examples from the Slovene Classical karst landscapes that show important hydrologic variations are presented below. At Cerkniško Polje and Pivka valley, which are located on the boundary of AdriaticBlack Sea watershed, flow bifurcations can be observed (Fig. 2): During low-water conditions, groundwater from the Javorniki Mountains and Pivka Valley drain toward Planinsko Polje to the northeast. In high-water conditions, water levels rise and a groundwater divide forms below the Javorniki Mountains so that a part of the area drains towards Pivka Valley to the southwest.

Furthermore, due to groundwater fluctuations and weak connections between different karst conduits, several intermittent lakes of different size, temporal duration and frequency occur in this region. The largest one is the lake of Cerkniško Jezero, which can extend over $26 \mathrm{~km}^{2}$ and contain more than 82 million $\mathrm{m}^{3}$ of water.

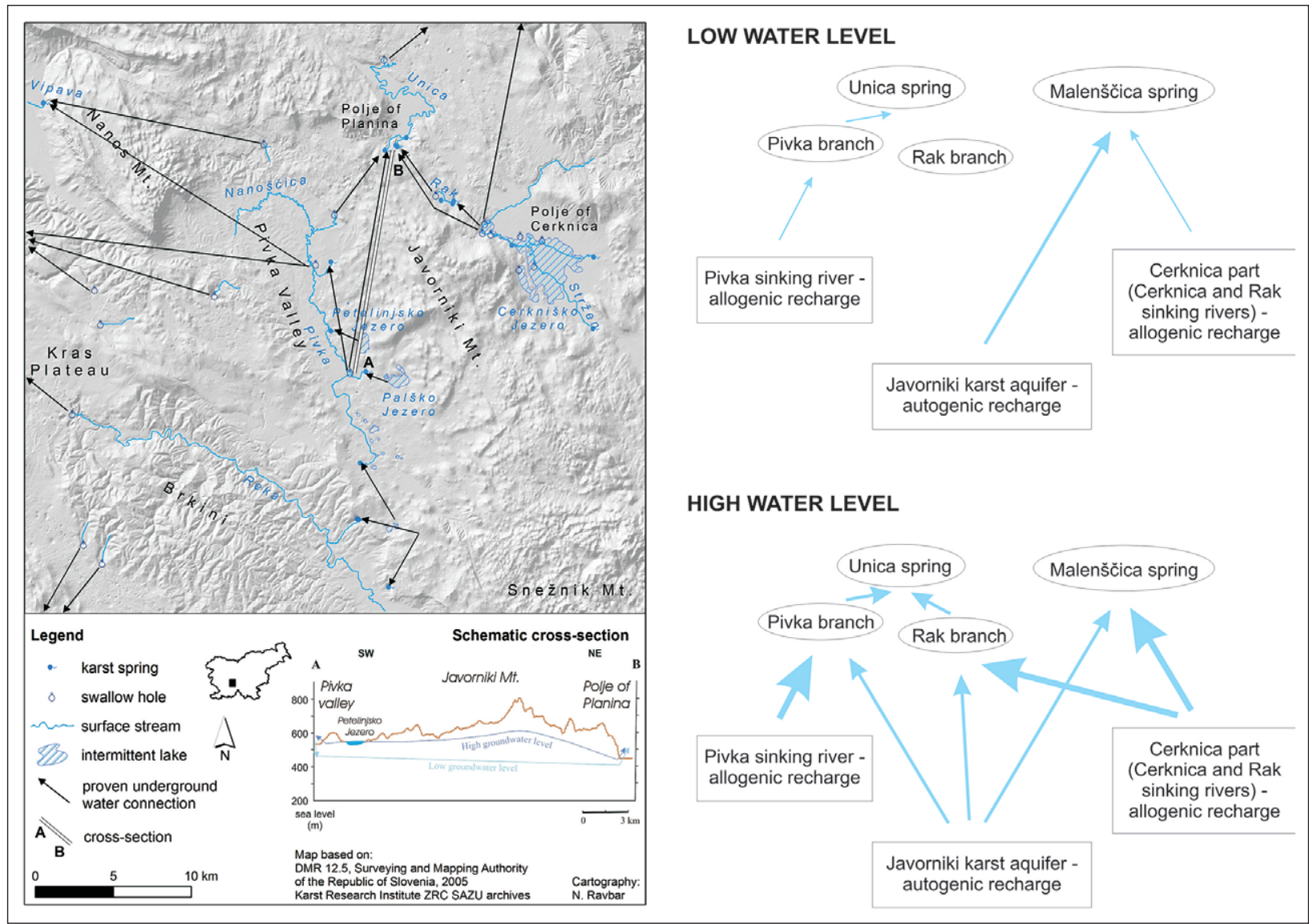

Fig. 2: Physical map of the Slovene Classical karst with the underground connections proven by tracer tests, a schematic cross-section of the area showing flow bifurcation, and the conceptual model of the aquifer system functioning during low-and high-water conditions with wider arrows indicating proportionately great flow volume (modified after Gospodarič \& Habič 1976; Kogovšek et al. 1999; Gabrovšek et al. 2010; Petrič 2010; Ravbar et al. 2012). 
The lake usually fills twice per year via springs and estavelles, but remains empty in dry years; in wet years, it occurs several times per year and/or does not dry up entirely (Kovačič 2010).

Malenščica Spring is the principal spring of the area and is a regionally important drinking water supply that outflows into Planinsko Polje. Nearby Unica Spring outflows from the well known Planinska Jama, where two subsurface river channels (Rak and Pivka branches) converge. In recent years, several tracer tests have been done in different hydrological conditions (Gabrovšek et al. 2010; Petrič 2010; Ravbar et al. 2012). The results revealed that the relations between various contribution areas to the springs are strongly dependant on temporal hydrologic conditions (Fig. 2).

In general, Malenščica Spring is recharged mainly from the Cerknica direction and Javorniki karst aquifer, and there is no direct connection with the ponor of the Pivka River sinking in Postojnska Jama. At high water levels, inflows from the Cerknica part dominate. The outflow from Malenšcica Spring is thus bounded and the Rak branch in Planinska Jama acts as an overflow. The Rak branch is recharged from both the Cerknica and Javorniki parts, and the Pivka branch from Javorniki and the Pivka parts. At low waters, after the emptying of the intermittent Cerkniško Jezero, the proportion of inflow from the Javorniki part to the Malenščica Spring is more important. The Rak branch progressively drains and Unica Spring is principally fed by the Pivka branch. Studies made at higher groundwater level showed that the apparent dominant flow velocities were for two to four times higher than in conditions of constant water level recession. In well developed conduit networks (e.g. cave system of Postojnska Jama) flow velocities during medium water levels were at least seventeen times higher in comparison to the velocities observed at low water levels.

Several other studies worldwide also showed considerable variations of groundwater flow velocities and directions as a function of respective hydrologic conditions (e.g., Kogovšek \& Liu 2000; Göppert \& Goldscheider 2008; Pronk et al. 2007).

\section{VARIABILITY OF TRANSPORT PROCESSES}

The extent to which fissures or conduits are filled by a recharge pulse will determine the nature of the water flow and transport processes, and there may be variable lags between the input pulse and the response at the spring. Changes from laminar to turbulent flow may occur, resulting in higher transport velocities, shorter transit times, more effective transport of sediments and bacteria, and mobilization of DNAPLs (Dense Non-Aqueous Phase Liquids). Raising water table above the conduit ceiling induces changes from open-channel to pressurized flow. Storm water, together with contaminants, thus penetrate and are temporarily stored in the adjacent less karstified zones of the aquifer and the overlying unsaturated zone. Vadose conduits then become temporarily phreatic and change the nature of the karst drainage system. Groundwater flow velocities decrease in the transition from open channel to pressurized flow due to the increased head loss of pressurized flow compared to open channel flow.

Later, when the recharge decreases, the flooded zones are drained back again into the conduits and the temporarily stored water leaves the system slowly (Fig. 3). Solute matter may therefore persistent in the outflow for

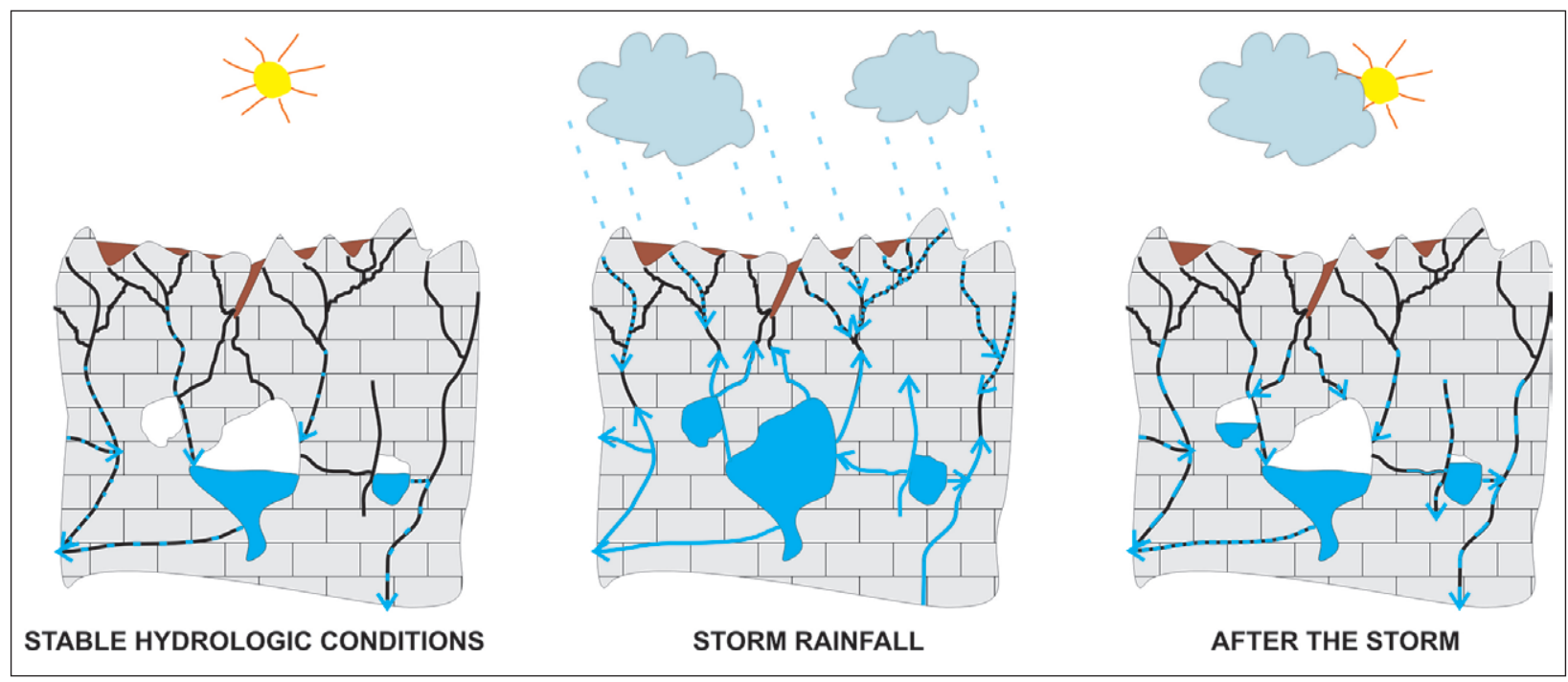

Fig. 3: Hydraulic interaction between karst conduits and the surrounding aquifer during different hydrologic conditions. 
longer periods, whereas particles may be attenuated in the aquifer (Cornaton \& Perrochet 2002).

In a study by Raeisi et al. (2007), changes in hydraulic flow of a conduit within the Mammoth Cave System were compared between partially-full pipe and full pipe conditions of the Logsdon River. Analysis of temperature, electrical conductivity, water level and velocity demonstrated relationships to the geometry to conduit and fluid transport behavior. When Logsdon River exceeds the capacity of its conduit, open channel flow changes into pressurized flow. Meanwhile, initial minimums in electrical conductivity represented the early movement of storm water through the conduit, while the subsequent second minimum was interpreted as storm water temporarily stored in adjacent areas that drained back into the conduit when the water level was decreasing. Changes in electrical conductivity during partially-full pipe conditions were mainly controlled by external recharge conditions, such as the behavior of sinking streams.

Similarly Goldscheider (2005) observed different breakthrough curves when tracing in the Hochifen-Gottesacker area in the Austro-German Alps during lowand variable high-flow conditions. During the experiment under low-flow conditions, the outflow of tracer was concentrated, continuous with a uniformly shaped breakthrough curve inferring to tracer transport that was restricted to a single fissure or a series of parallel fissures. On the contrary, due to the sudden increase of hydraulic pressure in the conduits and the rise of the water table during the experiment under variable flow conditions, the tracer breakthrough curves began with extremely steep increases in tracer concentration. The first appearance of the tracer coincided with its maximum concentration and after the steep decrease in the concentrations the outflow of the tracer persisted for several weeks. Such behavior indicates quick transfer of the tracer through preferential flow paths, followed by slow depletion from the low permeability volumes.

\section{VARIATIONS OF SPRING WATER PROPERTIES}

Karst springs represent the recharge from their entire aquifer systems. They reflect water flow characteristics within the systems and may reveal possible contamination in their catchments. Owing to fast and strong reactions of karst systems to variable recharge conditions, karst springs generally result in sudden variations of discharge, physical, chemical, isotopic and microbiological water composition (Ryan \& Meiman 1996; Katz et al. 1998; Auckenthaler et al. 2002; Vesper \& White 2003). There is a lot of literature on the variability of spring water characteristics, particularly the interpretations of dif- ferent time series variables (hydrographs, chemographs, turbidigraphs, etc.) on both seasonal time scales and individual storm events.

Generally, discharge rates may vary by many orders of magnitude and may include abrupt changes in water quality. This is a key problem for water suppliers, because otherwise safe water sources may suddenly be charged with high levels of contaminants, such as DNAPLs (Loop \& White 2001), toxic metals (Vesper \& White 2003) or fecal and pathogenic bacteria (Pronk et al. 2007).

An example of the variable properties of spring water is Hannetôt Spring, an important karst water source in Normandy, France (Massei et al. 2003; Fournier et al. 2007). The spring drains a chalk binary karst system. It is often characterized by high turbidity and phosphate concentrations, which poses potential health problems because of the great ability of bacteria to sorb onto particulates. Therefore the analyses of turbidity dynamics was used to characterize the direct transfer and re-suspension of components induced by the change of recharge conditions. The results reveal that after a recharge increase, a primary turbidity peak that coincides with a decrease in electrical conductivity and increase of phosphates indicates direct transfer of surface water infiltrated at a swallow hole. A secondary turbidity peak coincides with an increase in discharge and nitrate concentrations which indicate groundwater level rising and diffuse infiltration. This peak corresponds to re-suspension of intraclastic sediments induced by pressure transfer, which allows the increase of velocity and change from laminar to turbulent flow inside the karst conduits. This information can be used to optimize water treatment or disconnect the spring from the distribution network.

However, water quality variability includes much valuable hydrogeologic information. An example is the anomalous behavior of electrical conductivity observed at a typical karst spring in Slovenia (Ravbar et al. 2011). The spring is mainly recharged by diffuse infiltration. As a function of the hydrologic conditions, the groundwater table in its catchment fluctuates several tens of meters which can be observed in a cave near the spring and in the two intermittent lakes in its catchment. After typical response of the spring during several high-flow events, electrical conductivity rises again and remains elevated during the entire high-flow period, typically $20-40 \mu \mathrm{S} / \mathrm{cm}$ above the baseflow value. Based on the tracer tests results and other considerations (water balance, topography, geologic structure) this behavior is explained by variable catchment boundaries and variations of flow directions (Fig. 4); when the water level in the aquifer rises, the catchment expands, incorporating zones of groundwater with higher electrical conductivity, caused by higher unsaturated zone thickness and subtle lithologic changes. 
A

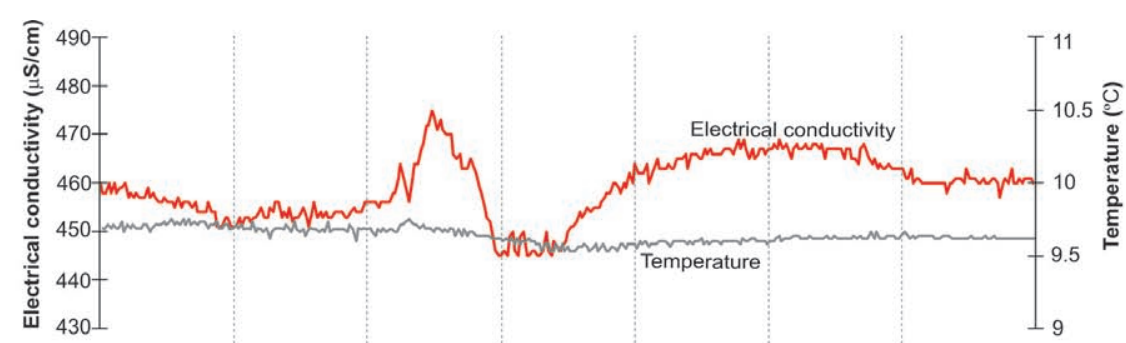

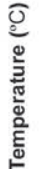

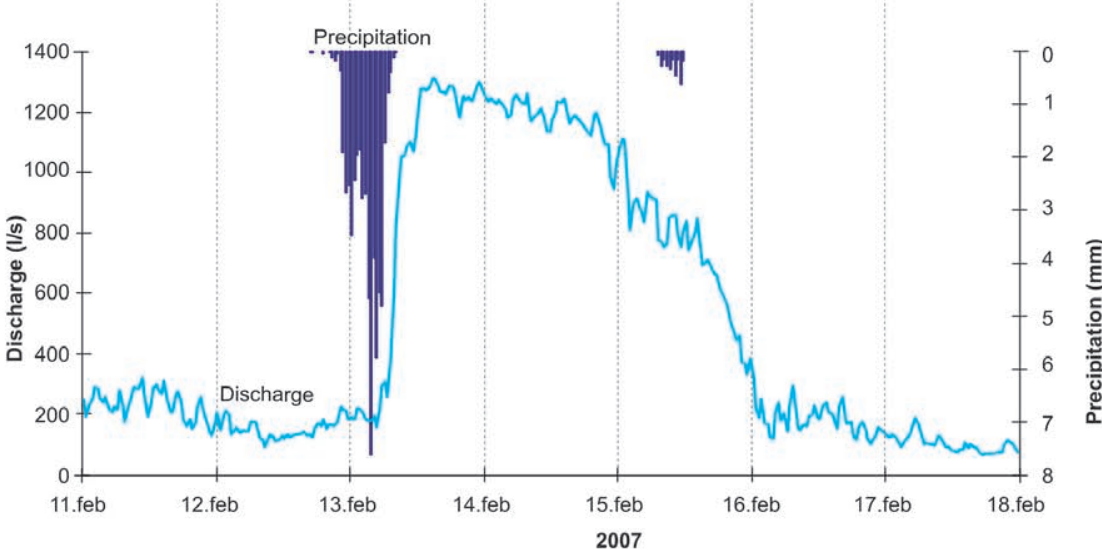

B
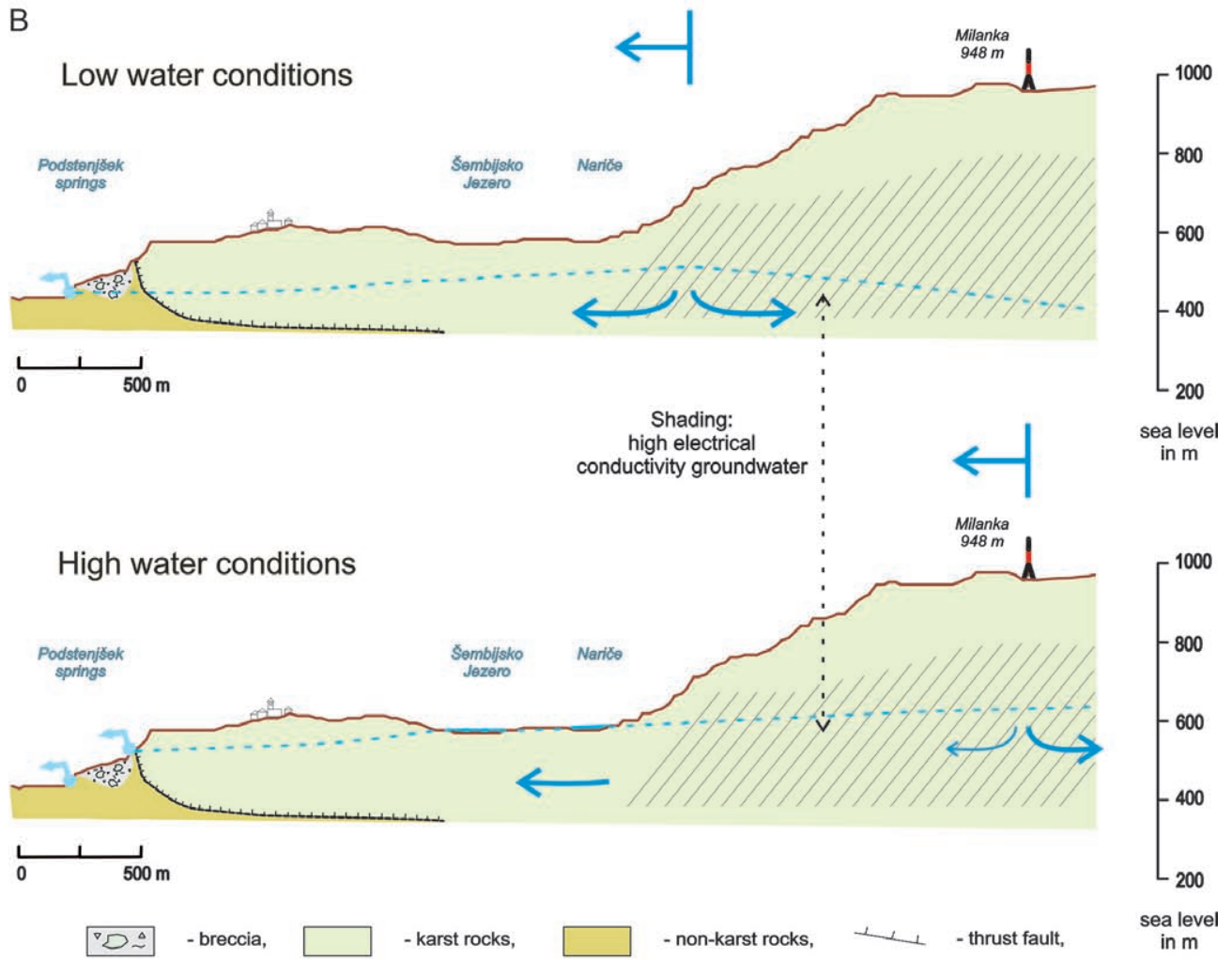

$\leftarrow$-drainage devide, $\longleftarrow$-groundwater flow, $\quad-\quad$ - spring.

Fig. 4: A) Anomalous behavior of electrical conductivity observed at the Podstenjšek spring following short but intense rainfall. B) Conceptual model for the anomalous electrical conductivity variability induced by variable catchment boundaries and variations of flow directions (modified after Ravbar et al. 2011). 


\section{INVESTIGATION TECHNIQUES}

In karst landscapes, rivers and streams only occasionally flow on the surface. Subterranean drainage through mostly unknown and unpredictable flow paths prevail. In high karst plateaus and mountainous karst regions, the water table is often very deep below the surface, sometimes several hundreds of meters deep and inaccessible or too expensive for drilling water wells (Audra et al. 2003; Zhu et al. 2007; Plan et al. 2009). Therefore, in many situations, karst groundwater can only be observed in karst springs and some caves.

Caves that are large enough for humans to enter offer the unique opportunity for direct observation of water seepage through the unsaturated zone (Emblanch et al. 2003; Williams 2008; Kogovšek 2010) or consolidated water flow as cave streams in karst conduits and channels (Perrin et al. 2003; Groves \& Meiman 2005; Ravbar et al. 2012). Karst springs represent natural outflows of groundwater from the aquifer. Due to poor surface access, they represent ideal spots for the insight into the underground. However, they are typically sparsely distributed, but may be very large, achieving discharge values of some tens of $\mathrm{m}^{3} / \mathrm{s}$. Nevertheless, karst springs are regarded as important monitoring points and are commonly used as monitoring locations and to collect data of karst hydrogeological regimes (Shuster \& White 1971; Bonacci 2001; Bakalowicz 2005).

Due to the inherent characteristics of karst described above, conventional hydrologic and hydrogeologic investigation methods are often of limited value or fail when applied to karst. For example, hydraulic measurements in boreholes provide useful information about subsurface aquifers, but the heterogeneity of karst aquifers poses a real challenge in conventional well logging since it is often difficult to drill a successful borehole intersecting preferential flow paths within the surrounding rock. Boreholes are also often not really representative of the organization and functioning of the karst aquifer (Drogue 1980; Jeannin \& Sauter 1998; Worthington \& Ford 2009). Characterizing and quantifying the effects of temporal hydrologic variability thus requires special adaptations of the classical methodological approaches of sampling and monitoring strategies, and karst-specific methods as already emphasized by Bakalowicz (2005) and Goldscheider and Drew (2007).

Analyses of groundwater physiochemical parameters combined with karst spring hydrographs are often used to obtain information on the behavior and structure of karst aquifers, on different recharge mechanisms and on contamination problems. Event-based, quarterly or semi-annual sampling of groundwater physical and chemical properties and the combined interpretation of karst spring hydrographs and chemographs is the most widespread technique used for indicating aquifer characteristics (Shuster \& White 1971). Recently, many studies were based on monitoring and analyzing parameters such as detailed water chemistry (e.g., Ryan \& Meiman 1996; Grasso et al. 2003; Birk et al. 2004; Liu et al. 2004; Mudarra \& Andreo 2010), dissolved or total organic carbon (DOC/TOC) and turbidity (e.g., Emblanch et al. 1998; Batiot et al. 2003; Massei et al. 2006; Pronk et al. 2006), as well as isotopes (e.g., Lee \& Krothe 2003; Gainon et al. 2007).

Due to abrupt changes in groundwater level, high and rapid variations of discharge, chemical and microbial constituents, continuous high-resolution records of karst water quality and aquifer behavior have proven very use-
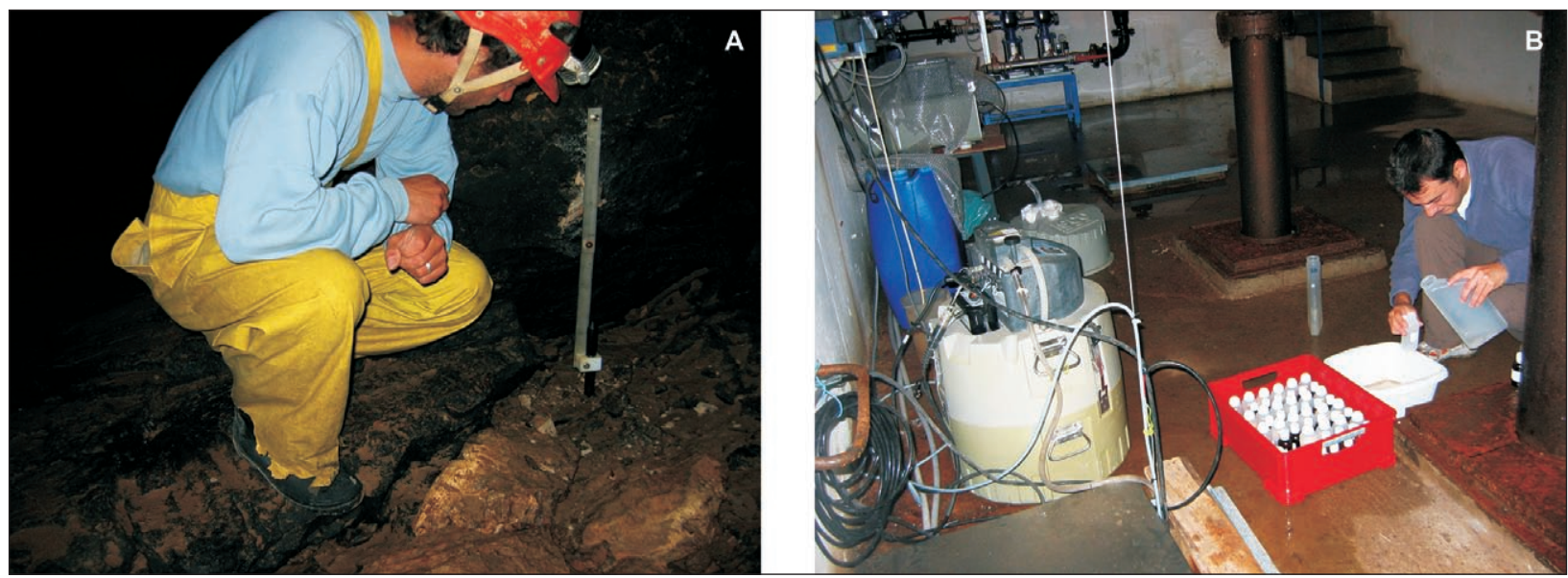

Fig. 5: A) Cave stream monitoring of natural parameters (water level, temperature and electrical conductivity), Pivka branch of Planinska Jama, Slovenia. B) Automatic sampler at Malenščica Spring, Slovenia (Photos: N. Ravbar). 
ful for the interpretation of temporal variability and of the functioning of karst aquifer systems (Fig. 5). Due to rapid aquifer responses, significantly shorter sampling intervals during high-flow events need to be employed. The study of Liu et al. (2007) stressed the need for continuous hydrogeochemical monitoring for at least one

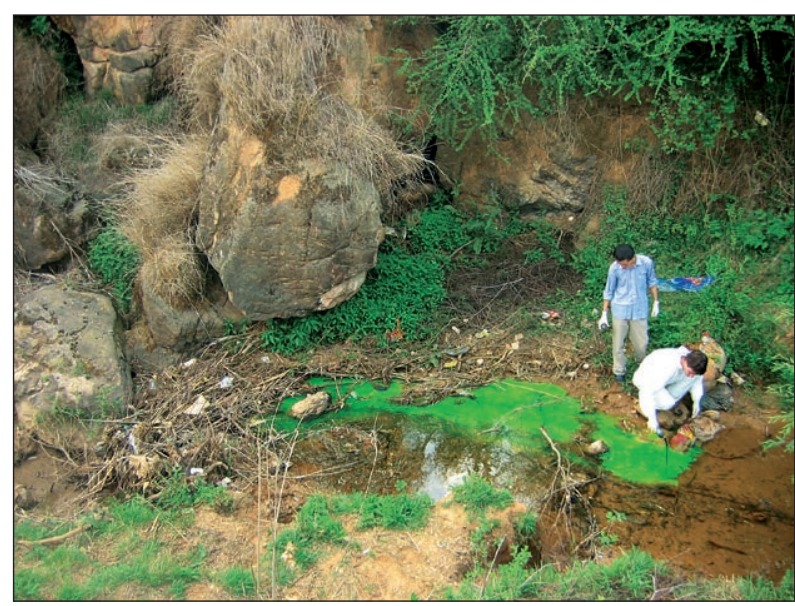

Fig. 6: Injection of $50 \mathrm{~g}$ of uranine into a stream sinking at Qiaotou Ponor in central Yunnan Province, China (Photo: N. Ravbar). hydrological year, including detailed seasonal, diurnal and storm-scale patterns in order to reveal highly accurate dynamics and variability of the system's behavior.

In addition, tracer techniques using artificial tracers can be complementary to defining contribution/ catchment areas, investigating underground water flow characteristics and transport of matter in different hydrological conditions (Käss 1998; Benischke et al. 2007). Detailed breakthrough curves (BTC) and tracer recovery provide data on hydraulic connections, dispersivity, and underground flow rates in the system. The advantage of the tracer method is generally controlled injection conditions (selection of injection points, injection mode; Fig. 6), however, cost effective artificial tracing can most often only be applied in limited areas or over a small surface (Andreo et al. 2006).

The combined application of artificial and environmental tracers can be used to assemble the information of temporal variability of karst aquifers. However, to date only a few studies combined the study of natural and artificial tracers (e.g., Kogovšek 2001; Auckenthaler et al. 2002; Einsiedl 2005; Savoy 2007; Pronk et al. 2008; Ravbar et al. 2012).

\section{CONCLUSION}

The issues and examples presented here on the variability of groundwater flow and transport processes in karst, under different hydrologic conditions, illustrate the importance of temporal hydrologic variations in some karst aquifers on their behavior that may consequently have many implications particularly for changes in groundwater availability, contaminant transport and groundwater vulnerability.

Several tens of meters large water level fluctuations may result in a considerably variable thickness of the unsaturated zone, different surface-groundwater interactions and in divergent flow. This may cause decreasing unsaturated zone thickness, decreasing protectiveness of the overlying layers, and increasing vulnerability. Temporal variations may induce preferential flow to occur, which permit contaminants to bypass overlying layers that may otherwise attenuate them. Variations of flow directions can result in contributions from different parts of the aquifer to a particular spring, and thus in variable catchment boundaries which are crucial for source protection. Variations in groundwater flow velocities and variability of transport processes may drastically change the properties of water at the observation point and in- fluence the derived results and interpretation. Moreover, higher water flow velocities reduce underground retention. Some contaminants may be largely immobile during low-water conditions, as they might be stored in the unsaturated zone, in cave sediments or at the bottom of water-filled cavities. During high-flow events, these contaminants may be remobilized and cause sanitary problems.

Therefore, in areas of considerable hydrological variability, this specific need to be taken into account when executing different aquifer studies, modeling and interpretations, and when preparing various utilization and management strategies. An example of how temporal variability can be considered in water resource protection and management practices is its integration into vulnerability assessment (Ravbar \& Goldscheider 2007, 2009). Thus, a thorough understanding of water and contaminant transfer through the soil, epikarst, unsaturated zone and active conduit network toward springs or other drinking water withdrawal points are required in order to assure appropriate investigation and planning in karst or to avoid eventual environmental and socio-economic consequences of groundwater contamination. 


\section{REFERENCES}

Andreo, B., Goldscheider, N., Vadillo, I., Vías, J.M., Neukum, C., Sinreich, M., Jiménez, P., Brechenmacher, J., Carrasco, F., Hötzl, H., Perles, J.M. \& F. Zwahlen, 2006: Karst groundwater protection: First application of a Pan-European Approach to vulnerability, hazard and risk mapping in the Sierra de Líbar (Southern Spain).- Science of the Total Environment, 357, 54-73.

Auckenthaler, A., Raso, G. \& P. Huggenberger, 2002: Particle transport in a karst aquifer: natural and artificial tracer experiments with bacteria, bacteriophages and microspheres.- Water Sci Technol 46, 3, 131-138.

Audra, P., Quinif, Y. \& P. Rochette, 2003: The genesis of the Tennengebirge karst and caves (Salzburg, Austria).- Journal of Cave and Karst Studies 64, 3, 153-164.

Bakalowicz, M., 2005: Karst groundwater: a challenge for new resources.- Hydrogeology Journal, 13,1, 148-160.

Bakalowicz, M., Crochet, P., D’Hulst, D., Mangin, A., Marsaud, B., Ricard, J. \& R. Rouch, 1994: High discharge pumping in a vertical cave: fundamental and applied results.- In: Crampon, N. \& M. Bakalowicz (eds.). Basic and applied hydrogeological research in French karstic areas. COST Action 65. pp. 93-110, Montepellier, Millau.

Batiot, C., Emblanch, C. \& B. Blavoux, 2003: Carbone organique total (COT) et magnésium $(\mathrm{Mg} 2+)$ :deux traceurs complémentaires du temps de séjour dans l'aquifère karstique.- Geoscience, 335, 205-214.

Benischke, R., Goldscheider, N. \& C. Smart, 2007: Tracer techniques.- In: Goldscheider, N. \& D. Drew (eds.) Methods in Karst Hydrogeology. Taylor \& Francis, pp. 147-170, London.

Birk, S., Liedl, R. \& M. Sauter, 2004: Identification of localised recharge and conduit flow by combined analysis of hydraulic and physico-chemical spring responses (Urenbrunnen, SW-Germany).- Journal of Hydrology, 286, 1-4, 179-193.

Bonacci, O., 2001: Analysis of the maximum discharge of karst springs.- Hydrogeology Journal, 9, 328-338.

Bonacci, O., Pipan, T., Culver, D.C., 2009: A framework for karst ecohydrology.- Environ. Geol., 56, 891900.

Cornaton, F. \& P. Perrochet, 2002: Analytical 1-D dualporosity equivalent solutions to $3-\mathrm{D}$ discrete singlecontinuum models. Application to karstic spring hydrograph modeling.- Journal of Hydrology, 262, 165-176.
Drew D. \& H. Hötzl (eds.), 1999: Karst Hydrology and Human Activities.- International Contributions to Hydrogeology. A. A. Balkema, International Association of Hydrologists, pp. 322, Rotterdam.

Drogue, C., 1980: Essai d'identification d'un type de structure de magasine carbonates, fissurés [An attempt at identification of types of water storage in fissured carbonate rocks].- Mem Hydrogeol Ser Soc Geol Fr, 2, 101-108.

Einsiedl, F., 2005: Flow system dynamics and water storage of a fissured-porous karst aquifer characterized by artificial and environmental tracers.- Journal of Hydrology, 312, 312-321.

Emblanch, C., Blavoux, B., Puig, J.M. \& J. Mudry, 1998: Dissolved organic carbon of infiltration within the autogenic karst hydrosystem.- Geophysical Research Letters, 25, 9, 1459-1462.

Emblanch, C., Zuppi, G.M., Mudry, J., Blavoux, B. \& C. Batiot, 2003: Carbon 13 of TDIC to quantify the role of the unsaturated zone: the example of the Vaucluse karst systems (Southeastern France).- Journal of Hydrology, 279, 1-4, 262-274.

Ford, D. \& P. Williams, 2007: Karst hydrogeology and geomorphology.- Academic Division of Unwin Hyman Ltd, pp. 601, London.

Fournier, M., Massei, N., Bakalowicz, M., DussartBaptista, L., Rodet, J. \& J. P. Dupont, 2007: Using turbidity dynamics and geochemical variability as a tool for understanding the behavior and vulnerability of a karst aquifer.- Hydrogeology Journal, 15, $4,689-704$.

Gabrovšek, F., 2000 (Ed.): Evolution of karst: from prekarst to cessation. ZRC Publishing, ZRC SAZU, pp. 150, Ljubljana.

Gabrovšek, F., Kogovšek, J., Kovačič, G., Petrič, M., Ravbar, N. \& J. Turk, 2010: Recent results of tracer tests in the catchment of the Unica River (SW Slovenia).- Acta Carsologica 39, 1, 27-38.

Gainon, F., Goldscheider, N. \& H. Surbeck, 2007: Conceptual model for the origin of high radon levels in spring waters - the example of the St. Placidus spring, Grisons, Swiss Alps.- Swiss Journal of Geosciences, 100, 2, 251-262.

Goldscheider, N., 2005: Fold structure and underground drainage pattern in the alpine karst system Hochifen-Gottesacker.- Ecologae Geologicae Helvetiae, 98, 1, 1-17.

Goldscheider, N. \& D. Drew, 2007: Methods in Karst Hydrogeology. Taylor \& Francis, pp. 264, London. 
Göppert, N. \& N. Goldscheider, 2008: Solute and colloid transport in karst conduits under low- and highflow conditions.- Ground Water, 46, 1, 61-68.

Gospodarič, R. \& P. Habič, (ed.), 1976: Underground water tracing: Investigations in Slovenia 1972-1975.Third International Symposium of Underground Water Tracing (3. SUWT), pp. 312, Ljubljana, Bled.

Grasso, D.A., Jeannin, P.Y. \& F. Zwahlen, 2003: A deterministic approach to the coupled analysis of karst springs hydrographs and chemographs.- Journal of Hydrology, 271, 65-76.

Groves, C. \& J. Meiman, 2005: Weathering, geomorphic work, and karst landscape evolution in the Cave City groundwater basin, Mammoth Cave, Kentucky.- Geomorphology, 67, 1-2, 115-126.

Habe, F., 1966. Katastrofalne poplave pred našimi turističnimi jamami.- Naše jame, 8, 45-54.

Jeannin, P-Y. \& M. Sauter, 1998: Analysis of karst hydrodynamic behaviour using global approach: a review.- Bulletin d'Hydrogeologie, 16, 31-48.

Käss, W., 1998: Tracing technique in Geohydrology.- A. A. Balkema, pp. 581, Rotterdam, Brookfield.

Katz, B.G., Catches, J.S., Bullen, T.D. \& R.L. Michel, 1998: Changes in the isotopic and chemical composition of ground water resulting from a recharge pulse from a sinking stream.- Journal of Hydrology, 211, 1-4, 178-207.

Király, L., 2002: Karstification and groundwater flow. In: Gabrovšek, F. (ed.) Evolution of karst: from prekarst to cessation. ZRC Publishing, ZRC SAZU, pp. 155190, Ljubljana.

Király, L., Perrochet, P. \& Y. Rossier, 1995: Effect of the epikarst on the hydrograph of karst springs: a numerical approach.- Bulletin d'Hydrogeologie, 14, 199-220.

Klimchouk, A.B. \& D.C. Ford, 2000: Types of karst and evolution of hydrogeologic settings.- In: Klimchouk, A.B., Ford, D.C., Palmer, A.N. \& W. Dreybrodt (eds.) Speleogenesis: Evolution of karst aquifers. National Speleological Society, pp. 45-53, Huntsville, Alabama.

Kogovšek, J. \& H. Liu, 2000: Water tracing test in the Tianshengan region, Yunnan - China at high water level.- Acta Carsologica, 29, 2, 249-260.

Kogovšek, J., 2001: Monitoring the Malenščica water pulse by several parameters in November 1997.Acta Carsologica, 30, 1, 39-53.

Kogovšek, J., 2010: Characteristics of percolation through the karst vadose zone.- ZRC Publishing, ZRC SAZU, pp.168, Ljubljana.

Kogovšek, J., Knez, M., Mihevc, A., Petrič, M., Slabe, T. \& S. Šebela, 1999: Military training area in Kras (Slovenia).- Environmental Geology, 38, 1, 69-76.
Kovačič, G., 2010: An attempt towards an assessment of the Cerknica Polje water balance. ).- Acta Carsologica 39, 1, 39-50.

Kresic, N. \& Z. Stevanovic (eds.), 2010: Groundwater hydrology of springs: engineering, theory, management, and sustainability.- Butterworth-Heinemann, pp. 573, Burlington.

Lee, E.S. \& N.C. Krothe, 2003: Delineating the karstic flow system in the upper Lost River drainage basin, south central Indiana: using sulphate and $\delta 34$ SSO 4 as tracers.- Appl Geochem, 18, 145-153.

Liu, Z.H., Groves, C., Yuan, D.X., Meiman, J., Jiang, G.H., He, S.Y. \& Q.A. Li, 2004: Hydrochemical variations during flood pulses in the south-west China peak cluster karst: impacts of $\mathrm{CaCO}_{3}-\mathrm{H}_{2} \mathrm{O}-\mathrm{CO}_{2}$ interactions.- Hydrological Processes, 18, 13, 2423-2437.

Liu, Z.H., Li, Q., Sun, H.L. \& J.L. Wang, 2007: Seasonal, diurnal and storm-scale hydrochemical variations of typical epikarst springs in subtropical karst areas of SW China: Soil CO2 and dilution effects.- Journal of Hydrology, 337, 207-223.

Loop, C.M. \& W.B. White, 2001: A conceptual model for DNAPL transport in karst ground water basins.Ground Water, 39, 1, 119-127.

Massei, N., Wang, H.Q., Dupont, J.P., Rodet, J. \& B. Laignel, 2003: Assessment of direct transfer and resuspension of particles during turbid floods at a karstic spring.- Journal of Hydrol, 275, 1-2, 109121.

Massei, N., Dupont, J.P., Mahler, B.J., Laignel, B., Fournier, M., Valdes, D. \& S. Ogier, 2006: Investigating transport properties and turbidity dynamics of a karst aquifer using correlation, spectral, and wavelet analyses.- Journal of Hydrology, 329, 1-2, 244-257.

Milanović, P.T., 2006: Karst of Eastern Herzegovina and Dubrovnik littoral.- ZUHRA, pp. 362, Beograd.

Mudarra, M. \& B. Andreo, 2010: Hydrogeological functioning of a karst aquifer deduced from hydrochemical components and natural organic tracers present in spring waters. The case of Yedra Spring (Southern Spain).- Acta Carsologica, 39, 2, 261-270.

Perrin, J., Jeannin, P.Y. \& F. Zwahlen, 2003: Implications of the spatial variability of infiltration-water chemistry for the investigation of a karst aquifer: a field study at Milandre test site, Swiss Jura.- Hydrogeology Journal, 11, 673-686.

Petrič, M., 2010: Characterization, exploitation, and protection of the Malenščica karst spring, Slovenia.- In: Kresic, N \& Z. Stevanovic (eds.) Groundwater hydrology of springs. Engineering, Theory, Management, and Sustainability. Butterworth-Heinemann, pp. 428-441, Amsterdam. 
Plan, L., Decker, K., Faber, R., Wagreich, M. \& B. Grasemann, 2009: Karst morphology and groundwater vulnerability of high alpine karst plateaus.- Environ Geol, 58, 285-297.

Pronk, M., Goldscheider, N. \& J. Zopfi, 2006: Dynamics and interaction of organic carbon, turbidity and bacteria in a karst aquifer system.- Hydrogeology Journal, 14, 4, 473-484.

Pronk, M., Goldscheider, N. \& J. Zopfi, 2007: Particle-size distribution as indicator for fecal bacteria contamination of drinking water from karst springs.- Environmental Science and Technology, 41, 8400-8405.

Pronk, M., Goldscheider, N., Zopfi J. \& F. Zwahlen, 2008: Percolation and Particle Transport in the Unsaturated Zone of a Karst Aquifer.- Ground Water, 47, 3, 361-369.

Raeisi, E., Groves, C. \& J. Meiman, 2007: Effects of partial and full pipe flow on hydrochemographs of Logsdon river, Mammoth Cave Kentucky USA.- Journal of Hydrology, 337, 1-10.

Ravbar, N., 2007: The protection of karst waters.- ZRC Publishing, ZRC SAZU, pp. 256, Ljubljana.

Ravbar, N. \& N. Goldscheider, 2007: Proposed methodology of vulnerability and contamination risk mapping for the protection of karst aquifers in Slovenia.- Acta Carsologica, 36, 3, 461-475.

Ravbar, N. \& N. Goldscheider, 2009: Comparative application of four methods of groundwater vulnerability mapping in a Slovene karst catchment.- Hydrogeology Journal, 17, 3, 725-733.

Ravbar, N., Barberá J.A., Petric, M., Kogovsek, J. \& B. Andreo, 2012: Study of hydrodynamic behaviour of a complex karst system under low-flow conditions using natural and artificial racers (springs of the Unica River, SW Slovenia).- Environmental Earth Sciences, 65, 8, 2259-2272.

Ravbar, N., Engelhardt, I. \& N. Goldscheider, 2011: Anomalous behaviour of specific electrical conductivity at a karst spring induced by variable catchment boundaries: the case of the Podstenjšek spring, Slovenia.- Hydrological Processes, 25, 13, 2130-2140.
Ryan, M. \& J. Meiman, 1996: An Examination of ShortTerm Variations in Water Quality at a Karst Spring in Kentucky.- Ground Water, 34, 23-30.

Sass, I. \& U. Burbaum, 2010: Damage to the historic town of staufen (Germany) caused by geothermal drillings through anhydrite-bearing formations.Acta Carsologica, 39, 2, 233-245.

Savoy, L., 2007: Use of natural and artificial reactive tracers to investigate the transfer of solutes in karst systems.- PhD Thesis, University of Neuchâtel, pp. 194.

Shuster, E.T. \& W.B. White, 1971: Seasonal fluctuations in the chemistry of limestone springs: A possible means for characterizing carbonate aquifers.- Journal of Hydrology, 14, 93-128.

Vesper, D.J. \& W.B. White, 2003: Metal transport to karst springs during storm flow: an example from Fort Campbell, Kentucky/Tennessee, USA.- Journal of Hydrology, 276, 1-4, 20-36.

White, W.B., 1988: Geomorphology and hydrology of karst terrains.- University Press, pp. 464, New York, Oxford.

Williams, P.W., 2008: The role of the epikarst in karst and cave hydrogeology: a review.- International Journal of Speleology, 37, 1, 1-10.

Worthington, S.R.H., 1991: Karst hydrogeology of the Canadian Rocky Mountains. PhD Thesis, McMaster University, $380 \mathrm{p}$.

Worthington, S.R.H. \& D. Ford, 2009: Self-organized permeability in carbonate aquifers.- Ground Water, 47, 326-336.

Zhu, X.W., Chen, W.H. \& E. Lynch, 2007: Wulong karst systems and as an indicator of local tectonic uplift.Carsologica Sinica, 2007-02. 